\title{
Timber mobilization and habitat tree retention in low-elevation mixed forests in Switzerland: an inventory-based scenario analysis of opportunities and constraints
}

\author{
Christian Temperli $^{1}$ (D) $\cdot$ Golo Stadelmann $^{1} \cdot$ Esther Thürig $^{1} \cdot$ Peter Brang $^{1}$
}

Received: 7 February 2017/Revised: 12 July 2017/Accepted: 14 July 2017/Published online: 19 July 2017

(C) Springer-Verlag GmbH Germany 2017

\begin{abstract}
Timber use in central Europe is expected to increase in the future, in line with forest policy goals to strengthen local wood supply for $\mathrm{CO}_{2}$-neutral energy production, construction and other uses. Growing stocks in low-elevation forests in Switzerland are currently high as exemplified by the Swiss canton of Aargau, for which an average volume of $346 \pm 16 \mathrm{~m}^{3} \mathrm{ha}^{-1}$ was measured in the 3rd Swiss National forest inventory (NFI) in 2004-2006. While this may justify a reduction of growing stocks through increased timber harvesting, we asked whether such a strategy may conflict with the sustainability of timber production and conservation goals. We evaluated a range of operationally relevant forest management scenarios that varied with respect to rotation length, growing stock targets and the promotion of conifers in the regeneration. The scenarios aimed at increased production of softwood, energy wood, the retention of potential habitat trees (PHTs) and the conversion to a continuous cover management system. They were used to drive the inventory-based forest simulator MASSIMO for 100 years starting in 2007 using the NFI sampling plots in Aargau. We analyzed model outputs with respect to projected future growing stock, growth, timber and energy yield and harvesting costs. We found growing stock to drop to $192 \mathrm{~m}^{3} \mathrm{ha}^{-1}$ in 2106 if
\end{abstract}

Communicated by Eric R. Labelle.

Electronic supplementary material The online version of this article (doi:10.1007/s10342-017-1067-y) contains supplementary material, which is available to authorized users.

Christian Temperli

christian.temperli@wsl.ch

1 Swiss Federal Institute for Forest, Snow and Landscape Research WSL, 8903 Birmensdorf, Switzerland business-as-usual (BAU as observed between the 2nd and 3rd NFI) timber volumes were set as harvesting targets for the whole simulation period. The promotion of conifers and a reduction of rotation lengths in a softwood scenario yielded 25\% more timber over the whole simulation period than BAU. An energy wood scenario that reduced growing stock to $200 \mathrm{~m}^{3} \mathrm{ha}^{-1}$ by 2056 and promoted the natural broadleaved regeneration yielded $9 \%$ more timber than BAU before 2056 and $30 \%$ less thereafter due to decreasing increments. The softwood scenario resulted in higher energy yield than the energy wood scenario despite the lower energy content of softwood. Retaining PHT resulted in a reduction of timber harvest $\left(0.055 \mathrm{~m}^{3} \mathrm{ha}^{-1} \mathrm{yr}^{-1}\right.$ per habitat tree) and higher harvesting costs. Continuous cover management yielded moderate timber amounts throughout the simulation period, yet sustainably. Considering climate change, we discuss the risks associated with favoring drought- and disturbance-susceptible conifers at low elevations and emphasize that continuous cover management must allow for the regeneration of drought-adapted tree species. In conclusion, our simulations show potential for short-term increases in timber mobilization but also that such increases need to be carefully balanced with future forest productivity and other forest ecosystem services.

Keywords Central Europe $\cdot$ Empirical forest model MASSIMO · Energy wood - Forest inventory $\cdot$ Habitat tree $\cdot$ Timber mobilization

\section{Introduction}

The demand for timber is expected to increase throughout Europe (Ferranti 2014; Kraft 2015; Lauri et al. 2012; UNECE-FAO 2011). Forest policies promote timber 
mobilization to supply the regional timber industry and support research and development for innovative woodbased products and technologies (Federal Office for the Environment 2013; Nabuurs et al. 2015). These policies aim at reducing $\mathrm{CO}_{2}$ emissions by replacing more energyintensive construction materials such as concrete and steel and by substituting fossil fuel-based products in industrial and pharmaceutical production and in energy generation, e.g., with local woodchip heating networks (Dodoo et al. 2012; Werner et al. 2010). At the same time, government agencies engage in the forestry sector and the wood-based industries with regulations, subsidies and financial compensations for non-market forest ecosystem services. The preservation and promotion of biodiversity is an important forest policy goal in the Swiss Plateau (Imesch et al. 2015). Hence, conflicts among the multiple demands for forest ecosystem services may occur across time and space and need to be accounted for by forest management (Alrahahleh et al. 2017; Lexer and Brooks 2005).

During the last complete Swiss National Forest Inventory (3rd NFI: 2004-2006), growing stock in the Swiss Plateau was measured to be $408.5 \pm 8.2 \mathrm{~m}^{3} \mathrm{ha}^{-1}$ (Abegg et al. 2014), a high value, which may justify a general stock reduction through increased harvesting. However, such a reduction may compromise volume increment in future forests (Stadelmann et al. 2016) and may conflict with conservation efforts such as those to retain large trees as habitat for a diverse community of insects, birds and mammals that depends on the presence of old-growth forest attributes (Bütler et al. 2013; Peters et al. 2015). The growing stock of Norway spruce (Picea abies (L.) Karst), the economically most important tree species in the region, decreased by 31\% between 1993-1995 and 2009-2013 in the Swiss Plateau. At the same time, the growing stock of broadleaved trees increased throughout Switzerland (Camin et al. 2015). Reasons for this shift in tree species composition include storm damage and subsequent insect calamities but also a long-term shift from conifer planting to natural (broadleaved) regeneration and the promotion of noble broadleaved trees (i.e., oaks, Quercus spec.) by way of subsidies (Ammann 2013). The increasing share of broadleaved trees benefits biodiversity (e.g., Chauvat et al. 2011; Gärtner and Reif 2005; Sweeney et al. 2010) and improves the resistance and resilience of the forest to disturbances enhanced by climate change (Griess et al. 2012; Neuner et al. 2015). Many foresters in the Swiss Plateau and Southern Germany practice continuous cover forestry in uneven-aged mixed broadleaved forests, or use conversion treatments toward this goal (Knoke 2012; Schmidt 2009; Yousefpour and Hanewinkel 2014). However, the timber industry is concerned about the sustainable supply of softwood resources (Knoke et al. 2008; Läderach and Streiff 2016; Streiff 2014).
Scenario analyses using dynamic forest modeling have proven valuable to quantify such trade-offs and for demonstrating potential pathways for a synergetic provision of multiple forest goods and services (Pretzsch et al. 2008). For example, Verkerk et al. (2014) projected a $15 \%$ increase in the European roundwood production from 2010 to 2030 under a reference scenario and only a $3 \%$ increase under a scenario that also included the conservation of biodiversity. Using forest growth projections based on the German National Forest Inventory, Kroiher and Oehmichen (2010) showed that $7.3 \%$ of the potentially available roundwood per year would have to remain in the forest if deadwood is to be maintained at $11.5 \mathrm{~m}^{3} \mathrm{ha}^{-1}$. Process-based forest models are well suited to project how various indicators of ecosystem goods and services develop in response to management and to environmental change at scales from stands to relatively small landscapes and management units $\left(<50 \mathrm{~km}^{2}\right)$ (e.g., Fürstenau et al. 2006; Mina et al. 2016; Temperli et al. 2012). However, the limited availability of data required to drive relatively complex process-based models renders them unsuitable for simulations of forest development that are representative at regional to national scales (Barreiro et al. 2016).

In this study, we coupled the forest inventory-based management scenario model MASSIMO (Kaufmann 2001; Thürig et al. 2005; Thürig and Kaufmann 2010) with the timber harvesting productivity model HeProMo (Frutig et al. 2015). This empirical modeling framework combines the advantage of a landscape-scale, inventorybased model that statistically represents a relatively large case study area, with a relatively accurate representation of forest management and its costs, for which usually more process-oriented, stand-scale models are used (Mina et al. 2015; Seidl et al. 2007). The principal objective was to identify the potential and the constraints of operationally relevant management scenarios to increase timber mobilization in the Swiss canton of Aargau (forest area: $1404 \mathrm{~km}^{2}$ ), which is typical for the periurban areas of the Swiss Plateau, the adjacent Jura mountains and many similar areas in Central Europe. Specifically, we asked (1) how shortening rotation lengths and promoting conifers in a softwood scenario may influence timber yields and harvesting costs, (2) how a relatively drastic reduction in growing stock under a scenario to increase the yield of broadleaved energy wood may affect short- and long-term increment and timber harvest, (3) whether increased timber mobilization may be constrained by the retention of habitat trees in terms of timber yields and harvesting costs and (4) how continuous cover management that aims to maintain current growing stocks compares to scenarios that assume growing stock reduction in terms of short- and long-term timber yield. 


\section{Methods}

\section{Study area and data}

Forests in the canton of Aargau encompass 35\% (48,981 ha according to the 3rd Swiss NFI, Departement Bau, Verkehr und Umwelt 2010) of the area and intermix with other land uses. Our analyses are based on the data of the 2nd and 3rd NFI that comprise 228 permanently stocked sample plots, on which 2188 trees were recorded. Trees with $12-36 \mathrm{~cm}$ in diameter at breast height $(\mathrm{dbh})$ were recorded on a $200 \mathrm{~m}^{2}$ circle and trees $>36 \mathrm{~cm}$ dbh on a $500 \mathrm{~m}^{2}$ concentric circle (Brändli 2010; Stierlin and Zinggeler 2001; Traub et al. 2017). The NFI differentiates biogeographically and socioeconomically distinct regions, termed production regions. The canton of Aargau intersects with the production regions Plateau and Jura (68 and 32\% of sample plots, respectively). $95 \%$ of the forest area is between 290 and 680 (Plateau) and 340 and 690 (Jura) m a.s.l. Stocker et al. (2002) characterized the most frequent naturally occurring forest vegetation communities as mesic beech forests in the Plateau and as calcareous beech forests in the Jura. Past management favored Norway spruce and silver fir (Abies alba Mill.) as well as other conifers, such that in $200540 \%$ of the forest area were dominated by conifers (Departement Bau, Verkehr und Umwelt 2010). The 3rd NFI revealed a growing stock of $346 \pm 16 \mathrm{~m}^{3} \mathrm{ha}^{-1}$ for the canton of Aargau (Table 1). The volume proportions of conifers were $29 \%$ in the Jura and 51\% in the Plateau part of Aargau. $86 \%$ of the sample plots were classified as evenaged and $14 \%$ as uneven-aged forests. The cantonal forest service follows the guidelines on site-adapted broadleaf proportions by Stocker et al. (2002) to minimize disturbance risks and to prevent soil acidification (Morier 2012).
These guidelines provide minimum, recommended and natural proportions of broadleaved trees. Forest ownership breaks down to $66 \%$ communal corporations, $7 \%$ cantonal, $5 \%$ other public owners and $22 \%$ private owners (Departement Bau, Verkehr und Umwelt 2010). Forest reserves that have been contractually excluded from timber harvesting for $>50$ years account for $3 \%$ of the forest area (Wittwer 2016).

\section{Model of forest development}

MASSIMO is a dynamic, stochastic individual-tree model to simulate the development of tree populations on sample plots of the Swiss NFI. The empirical functions to simulate growth, removals due to forest management, mortality due to windthrow, self-thinning (density-dependent mortality) and regeneration of trees in 10-year time steps were parameterized based on NFI data (Kaufmann 2001; Thürig et al. 2005; Thürig and Kaufmann 2010). While these functions account for observed variation in growth conditions across space using site index, elevation and other spatial predictors, they do not account for temporal variations in climate.

MASSIMO accounts for the removal of trees due to shelterwood felling and thinning and for density-dependent, storm-induced and random-caused mortality. Removal intensities (i.e., removed basal area percentage), rotation length for shelterwood felling $\left(d_{\text {shelt }}\right)$ and the entry threshold for thinning $\left(d_{\text {thin }}\right.$, the basal area ratio of the focal decade to the decade before the last thinning with a default value of 1.1) can be defined by the user to create management scenarios. Alternatively, $d_{\text {shelt }}$ and $d_{\text {thin }}$ can be adjusted using an iterative approximation algorithm to match growing stock or harvesting targets that can be

Table 1 NFI results for the canton of Aargau by production regions

\begin{tabular}{|c|c|c|c|c|c|c|c|}
\hline $\begin{array}{l}\text { Production } \\
\text { region }\end{array}$ & $\begin{array}{l}\text { No. of } \\
\text { sample } \\
\text { plots }\end{array}$ & $\begin{array}{l}\text { Species } \\
\text { group }\end{array}$ & $\begin{array}{l}\text { Growing } \\
\text { stock } \\
\left(\mathrm{m}^{3} \mathrm{ha}^{-1}\right)\end{array}$ & $\begin{array}{l}\text { Timber harvest } \\
\left(\mathrm{m}^{3} \mathrm{ha}^{-1} \mathrm{yr}^{-1}\right)\end{array}$ & $\begin{array}{l}\text { Timber } \\
\text { harvest }+ \text { mortality } \\
\left(\mathrm{m}^{3} \mathrm{ha}^{-1} \mathrm{yr}^{-1}\right)\end{array}$ & $\begin{array}{l}\text { Gross increment } \\
\left(\mathrm{m}^{3} \mathrm{ha}^{-1} \mathrm{yr}^{-1}\right)\end{array}$ & $\begin{array}{l}\text { Stems } \\
>60 \mathrm{~cm} \mathrm{dbh} \\
\left(\mathrm{No} \mathrm{ha}^{-1}\right)\end{array}$ \\
\hline \multirow[t]{3}{*}{ Jura } & \multirow[t]{3}{*}{74} & Conifers & $98 \pm 17$ & $3.6 \pm 1.3$ & $3.9 \pm 1.3$ & $2.8 \pm 0.5$ & $3.1 \pm 1.1$ \\
\hline & & Broadleaves & $246 \pm 29$ & $6.8 \pm 1.4$ & $6.9 \pm 1.4$ & $6.5 \pm 0.8$ & $9.5 \pm 2.2$ \\
\hline & & Total & $343 \pm 33$ & $10.4 \pm 1.9$ & $10.8 \pm 1.9$ & $9.3 \pm 0.8$ & $12.6 \pm 2.6$ \\
\hline \multirow[t]{3}{*}{ Plateau } & \multirow[t]{3}{*}{154} & Conifers & $177 \pm 18$ & $9.3 \pm 1.4$ & $9.4 \pm 1.4$ & $6.8 \pm 0.6$ & $6.4 \pm 1.4$ \\
\hline & & Broadleaves & $171 \pm 15$ & $3.6 \pm 0.5$ & $3.8 \pm 0.6$ & $5.4 \pm 0.3$ & $5.8 \pm 1.0$ \\
\hline & & Total & $348 \pm 18$ & $12.9 \pm 1.5$ & $13.2 \pm 1.5$ & $12.1 \pm 0.5$ & $12.0 \pm 1.7$ \\
\hline \multirow[t]{2}{*}{ Total } & \multirow[t]{2}{*}{228} & Conifers & $151 \pm 13$ & $7.5 \pm 1.0$ & $7.7 \pm 1.0$ & $5.5 \pm 0.5$ & $5.4 \pm 1.0$ \\
\hline & & Broadleaves & $195 \pm 14$ & $4.6 \pm 0.6$ & $4.8 \pm 0.6$ & $5.6 \pm 0.3$ & $6.9 \pm 1.0$ \\
\hline Grand total & & & $346 \pm 16$ & $12.1 \pm 1.2$ & $12.4 \pm 1.2$ & $11.2 \pm 0.5$ & $12.2 \pm 1.4$ \\
\hline
\end{tabular}

Growing stock and no. of stems with dbh $>60 \mathrm{~cm}$ refer to values observed during the 3rd NFI. The annual timber harvest, the timber harvest together with random and wind-induced mortality and gross increment (including standing, in-growing, harvested and dying trees) refer to the interval between the 2 nd and the 3rd NFI. All quantities and their standard errors of the mean refer to stem wood over bark 
predefined for each decade and production region (Temperli et al. 2017). By default, shelterwood felling removes $80 \%$ of the trees on a sample plot in a first and the remaining trees in a secondary cutting. In accordance with the observations from the 2nd and 3rd NFI, plot-level thinning interventions remove $30 \%$ of the basal area in even-aged and $25 \%$ in uneven-aged forests. The removal probability of individual trees during thinning depends on $\mathrm{dbh}$, stand structure and production region and is modeled with a Weibull function that was parameterized with NFI data (Kaufmann 2001). For this study, we implemented the possibility to define the density per ha and the minimum dbh of trees that should be excluded from harvest in order to simulate the retention of habitat trees (Bütler et al. 2013). MASSIMO differentiates between even-aged and uneven-aged forests. In even-aged forests, both shelterwood felling and thinning are applied, and in uneven-aged forests, only thinning that perpetuates the stand structure is applied. Optionally, the user can specify the proportion of even-aged sample plots for which a conversion to unevenaged forest is to be simulated. The implementation of this conversion features dbh-dependent thinning probabilities that are calculated from the difference between the current dbh distribution and a dbh distribution that was fitted to data from NFI sample plots in uneven-aged forests (Kaufmann 2011).

Following shelterwood felling and windthrow, young trees (1-12 cm dbh) re-populate (i.e., regenerate) sample plots according to data from a randomly selected sample plot within the same production region (Jura or Plateau) and vegetation zone (foothills and submontane or lower montane). The proportion of conifers and broadleaves in newly regenerated tree cohorts can be adjusted by the user for individual sample plots to simulate scenario-specific tending regimes. In case the conifer proportion observed in the NFI is higher than what the user has supplied, randomly selected conifer saplings are replaced by beech saplings. In case the conifer proportion is lower than what the user has supplied, random broadleaved saplings are replaced with conifers. The species of these replacing conifers (in Aargau mostly Norway spruce and silver fir) is randomly determined based on probabilities that are specific to the forest vegetation community type of the NFI sample plot (Keller et al. 1998) (Table S1 in supplementary material). In addition to regeneration following stand replacement, MASSIMO accounts for regeneration that is independent from management and occurs throughout the simulations on all sample plots. When a young tree grows over the $12 \mathrm{~cm}$ dbh threshold, a certain number of saplings of trees of the same species are generated. This number and the saplings' probability to survive a decade were parameterized to approximate the number of trees that surpassed the $12 \mathrm{~cm}$ dbh threshold (ingrowth) between the $2 \mathrm{nd}$ and the 3rd NFI (see more details in electronic supplementary material). Regeneration in MASSIMO does not respond to changes in environmental or stand structural conditions.

\section{Management scenarios}

We developed five timber mobilization strategies in collaboration with representatives from the Forest division in the Department of Construction, Traffic and Environment of the Canton of Aargau. We aimed at a broad range of alternatives that represent the interests of the timber industry, environmental associations and the general public.

1. Business-as-usual (BAU): Regeneration and harvests were parameterized to approximate the proportions of conifers and broadleaves and the yearly harvesting amounts that have been observed between the 2 nd and the 3rd NFI.

2. Softwood: This scenario aimed at meeting the demands of the timber industry for sawmill-friendly $(20-40 \mathrm{~cm}$ dbh) spruce and fir timber. Rotations for shelterwood felling were shortened by 30 years with respect to values used in previous MASSIMO simulations (Hofer et al. 2011). This resulted in rotations of 60-80 years depending on site index for conifer-dominated sample plots and 80-100 years for broadleaf-dominated plots. Tending promoted conifers.

3. Energy: The high demand for energy and industrial wood is being met through a reduction of the growing stock to a predefined regional average within 50 years $(<2056)$. Tending favored the natural broadleaf proportion in the regeneration. We simulated three variants of this scenario by setting the targeted regional growing stock in 2056 to 150,200 and $250 \mathrm{~m}^{3} \mathrm{ha}^{-1}$ with the aim to show the potential effects of a broad range of timber mobilization strategies on future timber harvest, increment and forest structure. We labeled these variants as energy 150, energy 200 and energy 250.

4. Biodiversity: In this scenario, timber mobilization is being combined with the promotion of habitat for a wide range of species. The scenario reflects the goals of the nature conservation program of the canton of Aargau (Aargau 2012). These include adapting the species composition to site conditions by promoting the naturally regenerating broadleaves in the regeneration and securing old and large trees with particularly high conservation value (habitat trees, Bütler et al. 2013). We defined potential habitat trees (PHT) as trees of any species with $\mathrm{dbh}>60 \mathrm{~cm}$ and simulated four variants of this scenario. Three variants targeted a regional growing stock of $300 \mathrm{~m}^{3} \mathrm{ha}^{-1}$ allowing for a 
supply of a broad range of timber assortments, but differed in the number of PHT per ha excluded from harvesting (10, 20 and 30). Accordingly, we labeled these three variants as biodiversity 10 , biodiversity 20 and biodiversity 30 . A fourth extreme variant targeted a growing stock of $500 \mathrm{~m}^{3} \mathrm{ha}^{-1}$ implying reduced timber harvests, the promotion of late successional stands and dead wood accumulation. Such old-growth forest attributes are associated with a particularly rich fauna (Müller and Bütler 2010; Rosenvald et al. 2011). This fourth variant targeted $20 \mathrm{PHT} \mathrm{ha}^{-1}$ and was labeled as biodiversity $20-500$.

5. Continuous cover: This scenario aimed at converting current even-aged forests to uneven-aged forests using a continuous cover management system. Continuous cover forestry may combine timber production with the promotion of disturbance resistance and resilience as well as biodiversity using single-tree and/or group selection systems (Knoke 2012; Lafond et al. 2014; Pukkala et al. 2016) and has become increasingly popular among forest managers in the Plateau and other parts of Switzerland and Germany (Brang et al. 2014; Schmidt 2009). For this scenario, we assumed that the entire even-aged forest is being converted and that the species composition in the regeneration is maintained as observed during the 3rd NFI. Developments in growing stock and timber harvest result from dbh-dependent removal probabilities.

The scenario simulations were initialized with the data of the 3rd NFI representing the state of the forest in year 2006. The growing stock reductions (or increases as in the biodiversity $20-500$ variant) in the energy and biodiversity scenarios were equally distributed over five 10-year steps (i.e., $20 \%$ of the total reduction or increase in each time step) such that the targeted growing stock was reached in the year 2056. These growing stock reductions were implemented by adapting $d_{\text {shelt }}$ and $d_{\text {thin }}$ on even-aged sample plots using an iterative approximation procedure. On uneven-aged sample plots, we did not vary the thinning frequency (i.e., $\left.d_{\text {thin }}\right)$ and intensity $(25 \%$ of basal area removed per intervention) to preserve the uneven-aged forest structure. We used the silvicultural recommendations for "maximally acceptable" conifer and "natural" broadleaf proportions by Stocker et al. (2002) to implement the regeneration and tending prescriptions for the softwood, energy and biodiversity scenarios, respectively. These expert recommendations were available for each sample plot via a cantonal map of vegetation community types (Keller et al. 1998; Stocker et al. 2002). We ran each scenario simulation for ten decades until 2106 and replicated each simulation run 20 times, with 20 reducing the standard deviation caused by stochastic processes such as tree mortality and storms to an acceptable level while keeping computation time feasible.

\section{Calculation of output variables}

We quantified simulated forest development using growing stock $\left(\mathrm{m}^{3} \mathrm{ha}^{-1}\right)$, the volume share of conifers $\left(\mathrm{m}^{3} \mathrm{~m}^{-3}\right)$, the density of trees per ha with $\mathrm{dbh}>60 \mathrm{~cm}$ and yearly timber harvest and gross (see Table 1) increment (both $\mathrm{m}^{3} \mathrm{ha}^{-1} \mathrm{yr}^{-1}$ ). We calculated these metrics based on model output of growth, removals and mortality of stem wood over bark as described by Kaufmann $(2011,2001)$. The effect of the scenarios in terms of energy provision was quantified by the energy content of the harvested wood. To this end, we used Assmann's (1961) speciesspecific wood densities to calculate biomass from MASSIMO output (e.g., spruce: $390 \mathrm{~kg} \mathrm{~m}^{-3}$, beech: $560 \mathrm{~kg} \mathrm{~m}^{-3}$ ) and multiplied them with the following heat values: $5.0 \mathrm{kWh} \mathrm{kg}^{-1}$ for hardwood and $5.4 \mathrm{kWh} \mathrm{kg}^{-1}$ for softwood (Verscheure 1998). To evaluate the scenarios with respect to harvesting costs, we used the harvest and productivity model HeProMo (Frutig et al. 2015). This model is driven by plot-scale information on accessibility (e.g., slope, distance to road), preferred harvesting system (chainsaw, harvester, etc.) and extraction system (skidder, forwarder, cable yarding) from a survey, and harvested assortments (conifers or broadleaves, dbh). We stratified results to the NFI production regions Plateau and Jura (Fig. 1). Standard errors of means were calculated using the double sampling procedure developed by the Swiss NFI. This procedure combined the variation between sample plots and the variation between simulation replicates by summing the squares of the deviations from the mean (Köhl 2001).

\section{Results}

\section{Forest development and harvest under business-as- usual (BAU) management}

Growing stock for the whole of the canton Aargau dropped from $346 \pm 16$ to $192 \pm 30 \mathrm{~m}^{3} \mathrm{ha}^{-1}$ by 2106 if BAU harvesting was simulated (Figs. 2, 3). Proportionally, this drop was slightly more pronounced in the Plateau $(-46 \%)$ than in the Jura part of Aargau (-42\%). Concomitantly, increment for the whole of Aargau decreased from $11.2 \pm 0.5$ (2nd-3rd NFI) to $5.9 \mathrm{~m}^{3} \mathrm{ha}^{-1} \mathrm{yr}^{-1}$ for 2097-2106 (Jura $-31 \%$, Plateau $-54 \%$ ). Harvesting at BAU level could be maintained throughout the simulation in the Jura region, but not in the Plateau where harvesting dropped starting from 2057 due to reduced growing stock 


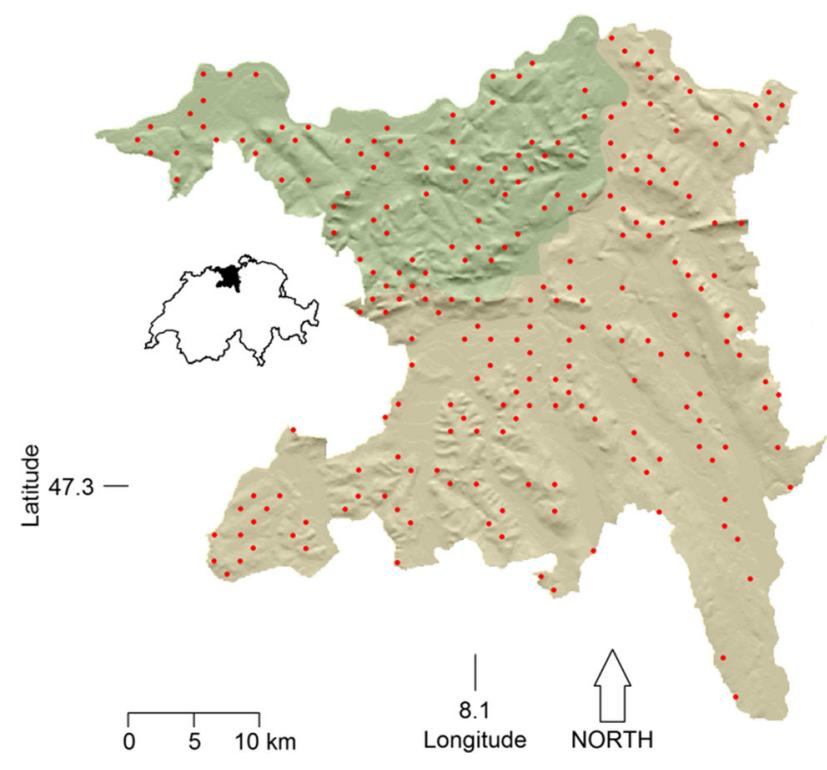

Fig. 1 Distribution of sample plots (red points) in the study area (canton of Aargau). The inset map shows the canton of Aargau (black) within Switzerland. Background colors indicate the NFI production regions (green Jura; beige Plateau). (Color figure online)

and increment. The density of large trees with $\mathrm{dbh}>60 \mathrm{~cm}$ decreased below the measured (3rd NFI) cantonal density of $12.2 \pm 1.4 \mathrm{stems} \mathrm{ha}^{-1}$ by the end of the simulation under BAU management. However, simulations under BAU and most other scenarios showed a hump in large tree density between the years 2027 and 2056. This hump reflects the age and size structure of the current forest. The distribution of diameters measured during the 3rd NFI shows a preponderance of conifers with $\mathrm{dbh}>60 \mathrm{~cm}$ in the Jura and $>50 \mathrm{~cm}$ in the Plateau (Fig. S4). These conifers continued to prevail in the $>60 \mathrm{~cm}$ dbh class in the forthcoming one to four decades. Thereafter, increased harvest reduced the density of trees with $\mathrm{dbh}>60 \mathrm{~cm}$. This reduction was more pronounced in scenarios where growing stock decreased more strongly (energy, softwood and BAU scenarios) and less pronounced where PHT were retained (biodiversity scenarios).

The standard errors of means (SEM) of total growing stock estimates for the whole of Aargau ranged from 5.6 to $15.8 \%$ of the mean (Figs. S5-S9). SEM were higher for timber harvesting (9.9-71.8\% of the mean of total harvest for the whole of Aargau; note that SEM expressed as percentage of the mean increases with decreasing absolute mean values) because treatments (no treatment, thinning, shelterwood cutting) varied among sample plots. SEM for number of stems with $\mathrm{dbh}>60 \mathrm{~cm}$, increment and harvesting costs were intermediate. SEM were higher in the Jura than in the Plateau, because less sample plots were available in the Jura, and increased with time as the differences among the individual simulation runs accumulated due to the random processes used to simulate, inter alia, tree mortality. These uncertainty estimates were similar in all scenarios.

\section{Timber yields and harvesting costs under the softwood scenario}

Shortening the rotation length by 30 years under the softwood scenario reduced overall growing stock to $254 \pm 34 \mathrm{~m}^{3} \mathrm{ha}^{-1}$ (-27\%) until 2106 (Fig. 2). This reduction was $-37 \%$ in the Plateau region and $-5 \%$ in the Jura, because in the Jura region the large increase in (conifer) increment partly compensated for the increased harvest due to a shorter rotation. Both shortening the rotation length and the promotion of conifers contributed to increased harvest under this scenario. Maximum timber harvest in the Jura was $14.6 \pm 3.7 \mathrm{~m}^{3} \mathrm{ha}^{-1} \mathrm{yr}^{-1}$ in 2076 . In the Plateau, the maximum timber yield was $12.4 \pm 1.8 \mathrm{~m}^{3} \mathrm{ha}^{-1} \mathrm{yr}^{-1}$ in 2046. Thereafter, timber yields declined to $7.2 \pm 1.5 \mathrm{~m}^{3} \mathrm{ha}^{-1} \mathrm{yr}^{-1}$ by 2106 due to the decline in growing stock and increment. Considering the whole simulation period, timber harvest under the softwood scenario was $25 \%$ higher than under BAU.

The harvesting costs per volume were highest under the softwood scenario followed by the biodiversity 20 and the energy 150 scenarios (Fig. 3). According to this pattern, harvesting costs increased with increasing conifer share and a higher share of small diameter trees in the harvest (see also Figs. S10, S11). The generally higher harvesting costs in the Jura than in the Plateau can be explained by the more rugged topography: Slopes in the Jura are steeper than in the Plateau (Fig. S12), and the proportion of sample plots that can be accessed with heavy machinery (i.e., wheeled and tracked harvesters), according to the NFI survey among foresters, is lower in the Jura with 11 versus 18\% (Fig. S13). However, the harvesting and skidding methods and per capita labor costs were assumed to be constant over the simulation period and among the scenarios. Hence, the development of harvesting cost was controlled by the effects of the different management scenarios on species composition and diameter distribution of the harvested trees. Harvesting by chainsaw, which is the most common harvesting method in Aargau (Fig. S13), is almost twice as costly if the stand is conifer- rather than broadleaf-dominated. For example, the modeled costs (felling, delimbing and bucking but no skidding) for harvesting conifers and broadleaves with $35 \mathrm{~cm}$ dbh by chainsaw are 41.90 and $23.42 \mathrm{CHF} \mathrm{m}^{-3}$, respectively (Frutig et al. 2015). This cost-disparity explains the rather high harvesting costs under the softwood scenario. 

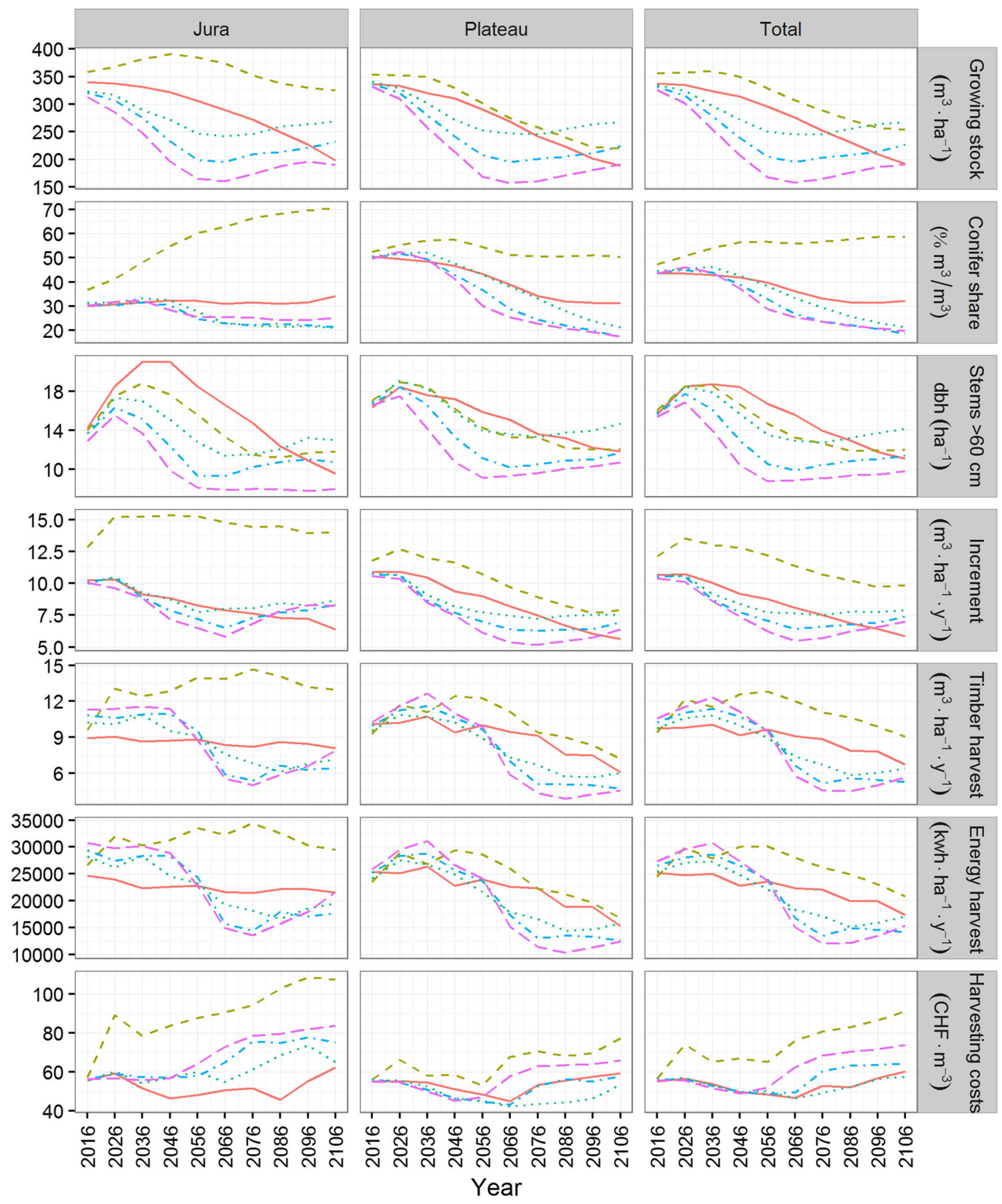

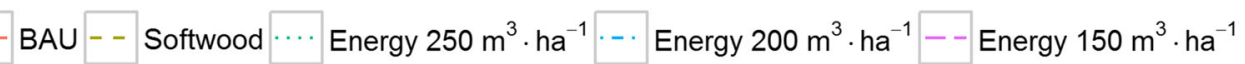

Fig. 2 Metrics for BAU, softwood and energy scenarios (for other scenarios: see Fig. 3). Please see supplementary figures S5-S9 for standard error of means

\section{Timber and energy yield under the energy scenario}

Growing stock under the energy scenarios developed as specified and reached the targeted growing stock $(150,200$ and $250 \mathrm{~m}^{3} \mathrm{ha}^{-1}$ ) in mid-century (Fig. 2). The promotion of the natural broadleaved regeneration under the energy scenarios decreased the volume share of conifers from 51 to $17 \%$ in the Plateau and from 29 to $21 \%$ in the Jura by 2106 under the energy 200 variant. Together with the reduction in growing stock, this shift toward a dominance of the slower growing broadleaves (Thürig et al. 2005) resulted in the highest increment drops among all 

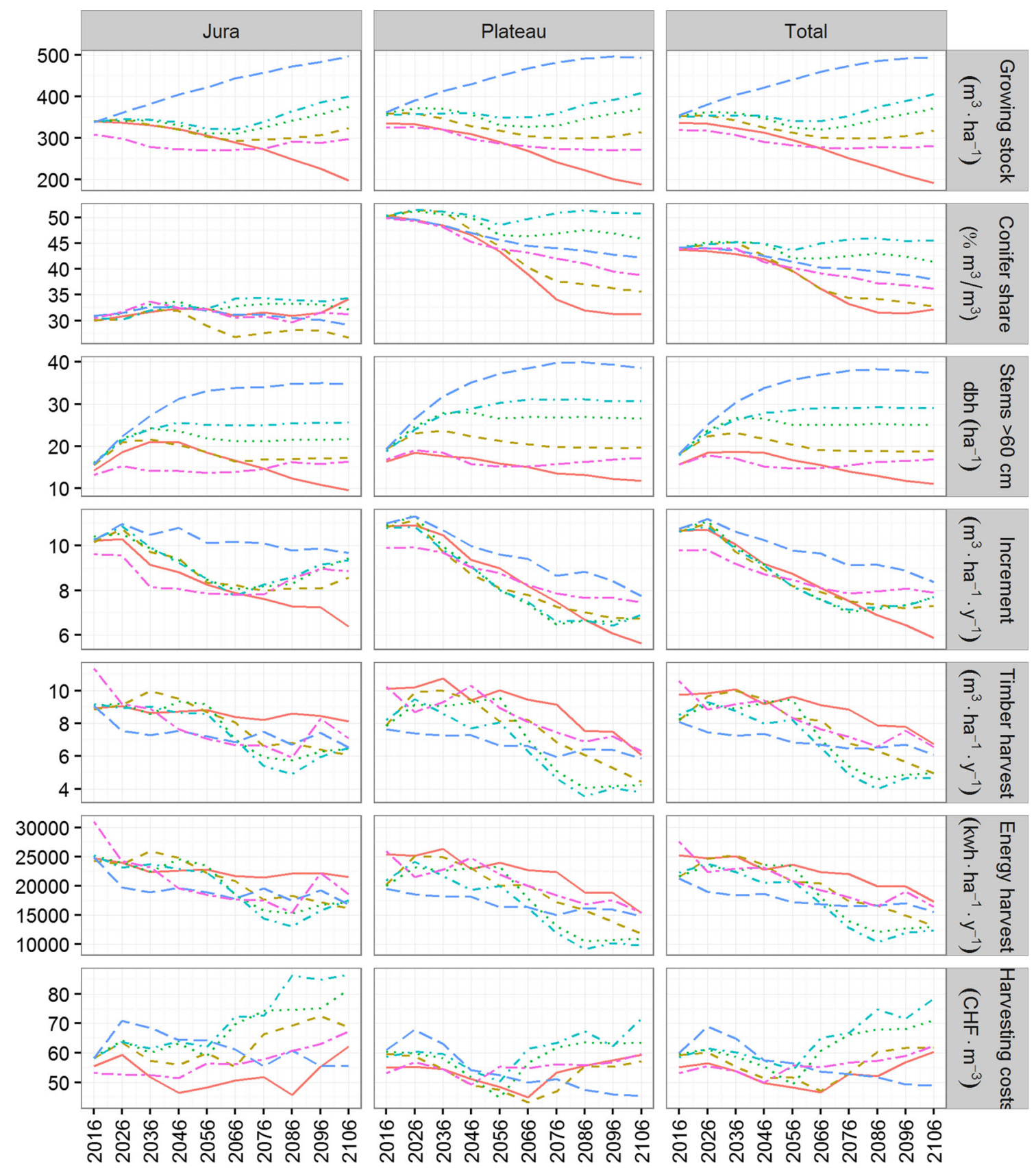

Year

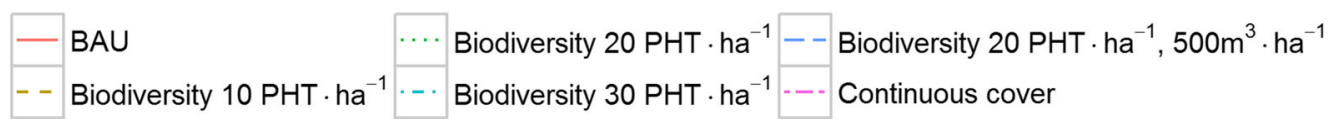

Fig. 3 Metrics for BAU, biodiversity and continuous cover scenarios (for other scenarios: see Fig. 2). Biodiversity scenarios differ with respect to the retained number of potential habitat trees (PHT). Please see supplementary figures S5-S9 for standard error of means

scenarios, e.g., $-47 \%$ from the 2 nd NFI-3rd NFI to the 2096-2106 period in the Plateau under the energy 150 scenario (Fig. 2). Consequently, timber harvests under the energy scenarios peaked ca. 2036 and declined thereafter. The cumulative harvest under the energy 150, energy 200 and energy 250 scenario exceeded BAU harvests by 14,9 and 3\% between 2007 and 2056, but fell behind BAU harvests by 37,30 and $20 \%$ in the long term (2057-2106). Consequently, timber harvest over the whole simulation period under the energy 150, energy 200 and energy 250 scenarios was 9,9 and $7 \%$, respectively, lower than under BAU. 
Energy yield developed almost directly proportional to timber harvest (Fig. 2). Hence, energy yield under the energy scenarios was lower than under the softwood scenario. The effect of the higher proportion of broadleaves under the energy scenario and thus higher energy density per $\mathrm{m}^{3}$ was too small to reverse the energy yield ranking among the energy and softwood scenarios as one might have expected.

\section{Effect of habitat tree retention on timber yield and harvesting costs}

The reduction of the growing stock to a target of $300 \mathrm{~m}^{3} \mathrm{ha}^{-1}$ in 2056 under the biodiversity scenarios could be realized if $10 \mathrm{PHT} \mathrm{ha}^{-1}$ were retained. Retaining $>10 \mathrm{PHT} \mathrm{ha}^{-1}$ increased the long-term abundance of PHT. In contrast, when PHT were not explicitly retained, the PHT density remained approximately constant as under the continuous cover scenario or decreased below the current average cantonal density of $12.2 \pm 1.4$ stems ha $^{-1}$ by the end of the simulation as under the BAU, softwood and energy scenarios (Figs. 2, 3). If 20 or 30 PHT were retained, growing stock decreased to $325 \pm 29$ and $341 \pm 29 \mathrm{~m}^{3} \mathrm{ha}^{-1}$, respectively, by 2056 for the whole canton of Aargau and increased again as the number and volume of retained PHT increased (see development of number of large trees with $\mathrm{dbh}>60 \mathrm{~cm}$ in Fig. 3). The increasing volume tied to PHT resulted in an increasing share of the standing volume to be inaccessible for timber harvest. This, in turn, caused timber harvest to drop sharply after 2056 (Fig. 3).

Timber harvest was generally lower in scenarios with a higher number of retained PHT (Fig. 3), and the harvests were lower than under BAU management under all variants of the biodiversity scenario with the exception of the period between 2017 and 2046 in the Jura if 10 PHT were retained. Aggregated over the whole simulation period, the retention of one additional PHT per ha resulted in $0.055 \mathrm{~m}^{3} \mathrm{ha}^{-1} \mathrm{yr}^{-1}$ less timber harvest. However, the uncertainty associated with timber harvest is relatively high in relation to this reduction (Fig. 4). The number of retained PHT also traded off with average harvesting costs. Retaining one additional PHT resulted in CHF 0.50 higher harvesting costs per $\mathrm{m}^{3}$ (Fig. 4). With less PHT being available for harvesting, more small trees had to be harvested to keep the growing stock at the $300 \mathrm{~m}^{3} \mathrm{ha}^{-1}$ target (Fig. S10). The higher number of trees to process resulted in higher costs per intervention (Frutig et al. 2015).

The similar developments in increment under scenarios with varying numbers of retained PHT indicate that PHT retention itself had a small effect on increment (Fig. 3). The decreasing increment under the biodiversity scenarios can be explained by the increased share of the slower

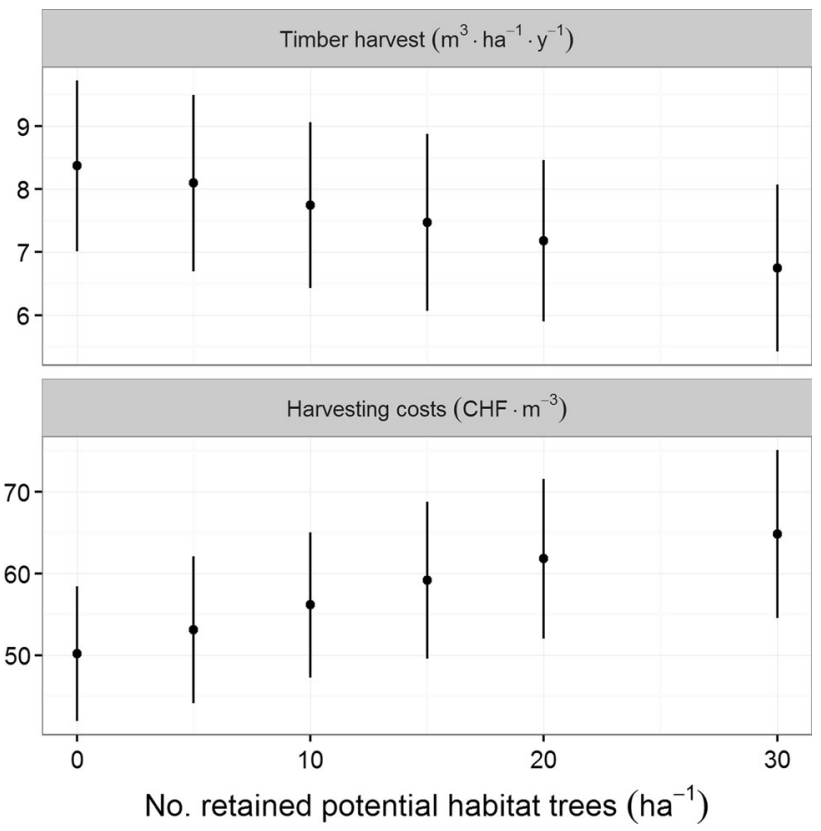

Fig. 4 Timber harvest (top) and harvesting costs (bottom) averaged over the whole simulation period (2007-2016) for variants of the biodiversity scenario that differed in the number of retained potential habitat trees. Error bars indicate standard error of means among sampling plots and simulation replicates

growing broadleaves in the regeneration. This effect was strong enough to cause a decrease in increment, even if growing stock increased as under the biodiversity 20-500 scenario (Fig. 3). However, retaining more PHT resulted in more conifers to remain in the forest and thus a slower realization of the anticipated reduction of the conifer share. Considering the whole canton of Aargau, the volume percentage of conifers remained $>45 \%$ if 30 PHT were retained and dropped to $<35 \%$ if $10 \mathrm{PHT} \mathrm{ha}^{-1}$ were retained (Fig. 3).

\section{Forest development and timber harvest under continuous cover management}

Continuous cover management resulted in growing stock to remain approximately constant as anticipated (Fig. 3). The share of conifers also stayed at a constant level in the Jura (31\%), but decreased slightly to $39 \%$ in the Plateau even though the species composition of the regeneration was simulated based on the observations of the 3rd NFI. The preponderance of large conifers that was observed in the 3rd NFI in the Plateau (Fig. S4) decreased over simulation time. This in turn resulted in a comparatively small reduction in increment and timber harvest in the Plateau (Fig. 3). Timber harvests under continuous cover management remained below BAU levels throughout the simulation period $(-8 \%)$, but exceeded those under the biodiversity 10 and energy scenarios in the second half of 
the simulation period (2057-2106) by 11 and $10 \%$, respectively.

\section{Discussion}

\section{Conifer promotion under the softwood scenario}

The regulation of species composition during regeneration strongly affected simulated growth and yield dynamics. The promotion of conifers through tending to the "maximally acceptable" conifer share influenced the species composition more than promoting the natural (mostly broadleaved) tree species composition. That is, the proportion of conifers increased much more under the softwood scenario as the proportion of broadleaves increased under the energy and biodiversity scenarios. This reflects the higher growth rate and thus faster establishment of conifers than broadleaves but also indicates that the conifer share of the observed (3rd NFI) regeneration was much closer to "natural" than to "maximally acceptable." The higher growth rate of conifers was also a reason for the higher increment and conifer share that we simulated in the Jura than in the Plateau under the softwood scenario. Another reason was the generally higher density of young trees $<12 \mathrm{~cm}$ measured in the 3rd NFI in the Jura $\left(4584 \pm 1151\right.$ stems ha $\left.^{-1}\right)$ in comparison with the Plateau $\left(2885 \pm 401\right.$ stems ha $\left.^{-1}\right)$ in the Plateau and thus the higher absolute number of conifers in the regeneration. Favoring these conifers under the softwood scenario boosted conifer increment. Favoring these conifers under the softwood scenario boosted conifer increment. Regeneration practices throughout the Swiss Plateau have shifted from conifer planting and promotion toward the promotion of the natural regeneration in the past 30 years (Departement Bau, Verkehr und Umwelt 2010). However, the legacy of conifer promotion in the past is still reflected in the measurements of the 3rd NFI that show higher conifer proportion in trees $>12 \mathrm{~cm}$ dbh in the Plateau relative to the Jura (Table 1; Fig. 2).

The $25 \%$ higher timber harvest under the softwood scenario in relation to BAU needs to be interpreted with the limitation of the here employed modeling approach. The MASSIMO inherent growth, mortality and regeneration sub-models do not account for climate change (Thürig et al. 2005). Hence, we likely overestimated growth and regeneration (i.e., sapling survival) and underestimated mortality rates of tree species that are particularly susceptible to projected changes in climate variables and disturbance regimes (Seidl et al. 2011; Temperli et al. 2013; Zubler et al. 2014). Norway spruce is the most abundant of these species due to past planting and promotion in Aargau, a canton which is mainly outside spruce's natural distribution range.
Considering the low resistance of Norway spruce to projected extensions of drought periods, and the concomitant growth reductions, mortality and pathogen (i.e., bark beetle) infestations (Boden et al. 2014; Jakoby et al. 2016; Lévesque et al. 2013; Netherer et al. 2015), the course of the softwood scenario in terms of increment and timber and energy yield seems overly optimistic.

Our calculations suggest that energy yield could be significantly increased by promoting conifers as under the softwood scenario. However, it is highly unlikely that such energy yields can be materialized. Timber prices are higher for sawtimber (WaldSchweiz 2017; WaldSchweiz et al. 2016) and the low wood density and thus comparably low energy content per volume make conifer wood inexpedient for heat generation. Moreover, our calculations with HeProMo suggested increasing harvesting costs as the proportion of conifers increased. However, we assumed harvesting methods to be constant over the simulation time. Timber quality is of minor importance for the production of energy wood. More economic harvesting methods may thus be feasible if energy wood production is the main management goal such that harvesting costs may actually be lower than in our calculations.

In sum, the promotion of conifers, in particular spruce, in conjunction with decreasing rotation lengths may increase timber yield in the short term, yet at higher harvesting costs. However, the risks associated with an increasingly warmer and drier climate increase over time. Species distribution and process-based forest succession modeling suggests that toward the end of this century oaks (e.g., Quercus petraea (Matt.) Liebl.) and other more drought-adapted tree species gain in dominance at the expense of beech and especially spruce in low-elevation central Europe (Dolos et al. 2016; Hanewinkel et al. 2012; Mette et al. 2013). This is projected to take place despite the large genetic adaptation potential of beech with respect to climate change (Kramer et al. 2010; Pluess et al. 2016). A management scenario that accounts for these projected changes would aim for high alpha and beta species diversity, so as to spread the risks associated with climate change as broadly as possible (Morin et al. 2014; Pedro et al. 2014).

\section{Short versus long-term timber yields under the energy scenario}

Relatively drastic growing stock reductions as simulated under the energy scenarios strongly increased timber yields over the BAU level until 2056. Thereafter, harvests dropped below the BAU level with the drop being higher the more the growing stock was reduced. The reduction in timber harvest as compared to BAU between 2057 and 2106 was greater than what was gained with growing stock reductions before 2056 in all variants of the energy and 
also the biodiversity scenarios. Hence, increasing timber mobilization by way of growing stock reduction comes at disproportionally large opportunity costs with respect to future harvests. This result confirms previous studies that found similar long-term increment and harvest reductions in scenarios of timber harvests that exceed current increments (Hofer et al. 2011; Stadelmann et al. 2016). Hence, our simulations suggest that extensive short-term timber mobilization in the canton of Aargau and similar areas in the Swiss Plateau and Jura entails substantial reductions in increment and thus timber harvest in the long term.

\section{Retention of habitat trees and timber harvests}

The effects of tree retention on the population dynamics of many forest dwelling taxa have been studied extensively (Rosenvald and Lõhmus 2008). However, only few studies have attempted to quantify the effects on timber yield and operational expenses. With a Hartman model approach, Koskela et al. (2007) found that tree retention increases socially optimal rotation ages and that the volume of retained trees needs to be higher than what current management recommendations suggest. They conclude that retention trees may cause additional costs for landowners. Perhans et al. (2011) found reduced cost-effectiveness when the conservation value was preferred over the economic value or a combination of the two as a criterion in the selection of tree retention patches, and Tikkanen et al. (2012) found self-thinning (i.e., density-dependent mortality) to be more cost-effective to promote dead wood than tree retention despite a reduction by up to $20 \%$ of the net present value of harvest revenues. Our study is in line with these studies in exemplifying the trade-off between conservation oriented and economic management goals.

A study conducted in the municipal forests of the town of Baden in the canton of Aargau estimated both the ecological and economic value (net wood value) of PHT (Niedermann-Meier et al. 2010). It concluded that retaining more than ca. five habitat trees per ha-the often cited minimum recommendation for central European beech forests (Bütler et al. 2013)_leads to substantial financial sacrifices. Thus, Niedermann-Meier et al. (2010) suggest relaxing a fixed number-per-ha recommendation and retaining trees of exceptional high ecological value (e.g., large oak standards in former coppice forests, wolf trees). Because past management selected trees for a high market but not necessarily ecological value, large trees currently often lack microhabitats (Brändli 2010). From an ecological perspective, it is thus particularly important that new PHT are selected already in early stand development phases. Our study shows that retaining habitat trees not only requires renouncing the financial income from potentially valuable trees but also generates additional costs per $\mathrm{m}^{3}$ of harvested wood. While our assessments of the losses and costs due to PHT retention seem small on a yearly and per ha basis, they may be substantial when added up and potentially discounted over decades and multiplied over large spatial scales.

\section{Continuous cover management}

Continuous cover management was aimed at maintaining current growing stocks in our simulations and did therefore not increase timber mobilization. It was therefore outperformed in terms of short-term timber harvest by the softwood and energy scenarios and by the biodiversity scenario variant with 10 retained PHT ha ${ }^{-1}$. However, continuous cover management yielded more timber than the most moderate variants of the energy and the biodiversity scenarios in the long term. With long-term increments decreasing under BAU and the softwood scenario being risky due to climate change-induced disturbances, continuous cover management may be the most sustainable scenario with respect to timber harvest in the long term. Previous studies on the economic performance of continuous cover management systems in comparison with conventional rotation forest management came to a similar conclusion. While they found a high dependency on the assumed interest rate (Hanewinkel 2001; Knoke 2009), it appears that continuous cover management is almost equally profitable if environmental risks are factored in (Knoke 2012; Knoke and Seifert 2008). Therefore, continuous cover management should be preferred for ecological reasons and to minimize disturbance risks (Tarp et al. 2005).

While our simulations of continuous cover management with the non-spatial Massimo model did not account for the size of cuttings (i.e., single-tree cutting vs. group selection cutting), the inherent assumption of the scenario implementation was that cuttings are smaller in area than the NFI sample plots $\left(500 \mathrm{~m}^{2}\right)$. To adapt forests in the Swiss Plateau to projected future climates and disturbance regimes, the promotion of a diverse species composition in the regeneration that also includes drought-adapted species such as oaks is pivotal (Hanewinkel et al. 2012; Temperli et al. 2012; Thom et al. 2017). As saplings of oaks and many other drought-adapted species need a lot of light to develop, continuous cover management must be flexible and embrace group selection and gap cuttings of $0.05-0.3$ ha (Brang et al. 2014).

\section{Conclusions}

We further developed the forest management scenario model MASSIMO and applied it to simulate a variety of operationally relevant timber mobilization scenarios for the 
canton of Aargau in the Swiss Plateau and Jura regions. The simulations showed that by drastically reducing current growing stocks and/or promoting fast growing conifers such as spruce, timber harvest could be increased over current levels for several decades. In our simulations, increment decreased with decreasing growing stock and increasing proportions of broadleaves, which suggests that such increased levels of timber harvest cannot be sustained in the long term (>2056). The large body of climate change impact studies shows that climate change-enhanced drought and disturbances limit the use of spruce to compensate for decreased increments due to reduced growing stock. Continuous cover management, in contrast, falls short in boosting short-term timber yield, but outperforms other scenarios in the long term. The currently high growing stocks may have led to the notion that growing stocks can be reduced without any significant effects on increment. Our simulations indicate otherwise in showing a strong trade-off over time with respect to increased timber mobilization and are thus relevant for strategic forest management decisions. We complemented previous assessments of the ecological and net wood value of habitat trees by quantifying the reduction in future timber harvest and the increase in harvesting costs with every new retained potential habitat tree. By illustrating and discussing the interactions and trade-offs associated with production (softwood and energy) and biodiversity oriented management scenarios, we provide indications for longterm, regional forest management planning. Methodological advances with respect to previous versions of MASSIMO (Kaufmann 2011; Stadelmann et al. 2016) include the possibility to simulate the retention of large PHT and a new set of management scenarios. These advances may be used to refine management scenarios for future regional and national applications of a climate-sensitive version of MASSIMO that is currently under development.

Further model development should implement the possibility to differentiate between tree species in the selection of PHT. This would allow the definition of scenarios that account for tree species-specific propensities to develop microhabitats. The retention of large oaks and other broadleaves may be more advantageous than the retention of spruce trees that are less likely to provide the necessary long-term stability for microhabitat development due to increased susceptibility to climate change and disturbances (Vuidot et al. 2011). Robust forest management decisionmaking must account for more indicators than just those related to timber production, growing stock and increment. Hence, our approach could be enhanced by an economic analysis that discounts future revenues using annuities (Hanewinkel et al. 2012) and a set of indicators that quantifies and evaluates forest biodiversity, recreation services, water retention potential, carbon balance and the resistance and resilience against climate change and disturbances (e.g., Köchli and Brang 2005; Mina et al. 2016; Blattert et al. 2017). A more accurate understanding of the synergies and trade-offs among such indicators may contribute to finding political solutions for schemes to compensate forest owners for expenses related to the provision of non-market forest ecosystem services.

Acknowledgements We thank Alain Morier (head), Dr. Peter Ammann and Fabian Dietiker from the Division of Forest in the Department of Construction, Traffic and Environment of the Canton of Aargau for their guidance during the development of management scenarios and critical assessments of simulation results, Edgar Kaufmann for sharing his thoughts on the implementation of tree regeneration in MASSIMO and Fritz Frutig and Dr. Renato Lemm for helpful comments on harvesting cost calculations with HeProMo. This research was funded by the Swiss National Science Foundation's 66th National Research Program (Grant No. 4066-40_136711).

\section{References}

Abegg M, Brändli U-B, Cioldi F et al (2014) Swiss national forest inventory-result table no. 131837: volume. Swiss Federal Research Institute WSL, Birmensdorf

Alrahahleh L, Ikonen V-P, Kilpeläinen A et al (2017) Effects of forest conservation and management on volume growth, harvested amount of timber, carbon stock, and amount of deadwood in Finnish boreal forests under changing climate. Can J For Res. doi:10.1139/cjfr-2016-0153

Ammann P (2013) Erfolg der Jungwaldpflege im Schweizer Mittelland? Analyse und Folgerungen (Essay). Schweiz Z Forstwes 164:262-270. doi:10.3188/szf.2013.0262

Assmann E (1961) Waldertragskunde: organische Produktion, Struktur, Zuwachs und Ertrag von Waldbeständen. BLV Verlagsgesellschaft, München

Barreiro S, Schelhaas M-J, Kändler G et al (2016) Overview of methods and tools for evaluating future woody biomass availability in European countries. Ann For Sci. doi:10.1007/s13595016-0564-3

Blattert C, Lemm R, Thees O et al (2017) Management of ecosystem services in mountain forests: review of indicators and value functions for model based multi-criteria decision analysis. Ecol Indic 79:391-409. doi:10.1016/j.ecolind.2017.04.025

Boden S, Kahle H-P, von Wilpert K, Spiecker H (2014) Resilience of Norway spruce (Picea abies (L.) Karst) growth to changing climatic conditions in Southwest Germany. For Ecol Manag 315:12-21. doi:10.1016/j.foreco.2013.12.015

Brändli U-B (2010) Schweizerisches Landesforstinventar. Ergebnisse der dritten Erhebung 2004-2006. Eidgenössische Forschungsanstalt für Wald, Schnee und Landschaft WSL; Bundesamt für Umwelt, BAFU, Birmensdorf, Bern

Brang P, Spathelf P, Larsen JB et al (2014) Suitability of close-tonature silviculture for adapting temperate European forests to climate change. Forestry 87:492-503. doi:10.1093/forestry/ cpu018

Bütler R, Lachat T, Larrieu L, Paillet Y (2013) Habitat trees: key elements for forest biodiversity. In: Integrating approaches as an opportunity for the conservation of forest biodiversity. European Forest Institute, pp 84-92

Camin P, Cioldi F, Röösli B (2015) Growing stock. For. Rep. 2015 Cond. Use Swiss For. Swiss Federal Office for the Environment 
FOEN, Bern, and Swiss Federal Institute for Forest, Snow and Landscape Research WSL, Birmensdorf, pp 32-33

Chauvat M, Titsch D, Zaytsev AS, Wolters V (2011) Changes in soil faunal assemblages during conversion from pure to mixed forest stands. For Ecol Manag 262:317-324. doi:10.1016/j.foreco. 2011.03.037

Departement Bau, Verkehr und Umwelt (2010) Waldinventar Aargau. Ergebnisse der Stichprobenaufnahmen. Departement Bau, Verkehr und Umwelt, Abteilung Wald, Aarau

Dodoo A, Gustavsson L, Sathre R (2012) Effect of thermal mass on life cycle primary energy balances of a concrete- and a woodframe building. Appl Energy 92:462-472. doi:10.1016/j.ape nergy.2011.11.017

Dolos K, Mette T, Wellstein C (2016) Silvicultural climatic turning point for European beech and sessile oak in Western Europe derived from national forest inventories. For Ecol Manag 373:128-137. doi:10.1016/j.foreco.2016.04.018

Federal Office for the Environment (2013) Forest Policy 2020. Visions, objectives and measures for the sustainable management of forests in Switzerland. Federal Office for the Environment FOEN, Bern

Ferranti F (2014) Energy wood: a challenge for European forests. Potentials, environmental implications, policy integration and related conflicts. EFI technical report 95, European Forest Institute

Frutig F, Holm S, Lemm R et al (2015) Kalkulation von Holzerntearbeiten: Das Produktivitätsmodell HeProMo. www.waldwis sen.net

Fürstenau C, Badeck FW, Lasch P et al (2006) Multiple-use forest management in consideration of climate change and the interests of stakeholder groups. Eur J For Res 126:225-239. doi:10.1007/ s10342-006-0114-x

Gärtner S, Reif A (2005) The response of ground vegetation to structural change during forest conversion in the southern Black Forest. Eur J For Res 124:221-231. doi:10.1007/s10342-0050065-7

Griess VC, Acevedo R, Härtl F et al (2012) Does mixing tree species enhance stand resistance against natural hazards? A case study for spruce. For Ecol Manag 267:284-296. doi:10.1016/j.foreco. 2011.11.035

Hanewinkel M (2001) Economic aspects of the transformation from even-aged pure stands of Norway spruce to uneven-aged mixed stands of Norway spruce and beech. For Ecol Manag 151:181-193. doi:10.1016/S0378-1127(00)00707-6

Hanewinkel M, Cullmann DA, Schelhaas M-J et al (2012) Climate change may cause severe loss in the economic value of European forest land. Nat Clim Change. doi:10.1038/nclimate1687

Hofer P, Altwegg J, Hässig J et al (2011) Holznutzungspotentiale im Schweizer Wald. Auswertung der Nutzungsszenarien und Waldwachstumsentwicklung, p 80

Imesch N, Stadler B, Bolliger M, Schneider O (2015) Biodiversität im Wald: Ziele und Massnahmen. Vollzugshilfe zur Erhaltung und Förderung der biologischen Vielfalt im Schweizer Wald. Federal Office for the Environment FOEN, Bern

Jakoby O, Stadelmann G, Lischke H, Wermelinger B (2016) Borkenkäfer und Befallsdisposition der Fichte im Klimawandel. In: Pluess AR, Augustin S, Brang P (eds) Wald im Klimawandel. Grundlagen für Aaptionsstrategien. Bundesamt für Umwelt BAFU Bern; Eidg. Forschungsanstalt WSL, Birmensdorf; Haupt, Bern, Stuttgart, Wien, pp 247-264

Kanton Aargau (2012) Naturschutzprogramm Wald, Zwischenbericht 2013, Ziele und Handlungsbedarf vierte Etappe. Abteilung Wald, Departement Bau, Verkehr und Umwelt, Kanton Aargau, Aarau

Kaufmann E (2001) Prognosis and management scenarios. In: Brassel P, Lischke H (eds) Swiss National Forest Inventory: methods and models of the second assessment. Swiss Federal Research Institute WSL, Birmensdorf, pp 197-206

Kaufmann E (2011) Nachhaltiges Holzproduktionspotenzial im Schweizer Wald. Schweiz Z Forstwes 162:300-311. doi:10. 3188/szf.2011.0300

Keller W, Wohlgemuth T, Kuhn N et al (1998) Waldgesellschaften der Schweiz auf floristischer Grundlage-statistisch überarbeitete Fassung der "Waldgesellschaften und Waldstandorte der Schweiz" von Heinz Ellenberg und Frank Klötzli (1972). Mitteilungen Eidgenöss Forschungsanstalt Für Wald Schnee Landsch 73:1-357

Knoke T (2009) Zur finanziellen Attraktivität von Dauerwaldwirtschaft und Überführung: eine Literaturanalyse. Schweiz Z Forstwes 160:152-161. doi:10.3188/szf.2009.0152

Knoke T (2012) The economics of continuous cover forestry. In: Pukkala T, von Gadow K (eds) Continuous cover forestry. Springer, Netherlands, pp 167-193

Knoke T, Seifert T (2008) Integrating selected ecological effects of mixed European beech-Norway spruce stands in bioeconomic modelling. Ecol Model 210:487-498. doi:10.1016/j.ecolmodel. 2007.08.011

Knoke T, Ammer C, Stimm B, Mosandl R (2008) Admixing broadleaved to coniferous tree species: a review on yield, ecological stability and economics. Eur J For Res 127:89-101. doi:10.1007/s10342-007-0186-2

Köchli DA, Brang P (2005) Simulating effects of forest management on selected public forest goods and services: a case study. For Ecol Manag 209:57-68. doi:10.1016/j.foreco.2005.01.009

Köhl M (2001) Inventory concept NFI2. In: Brassel P, Lischke H (eds) Swiss National Forest Inventory: methods and models of the second assessment. Swiss Federal Research Institute WSL, Birmensdorf, pp 19-46

Koskela E, Ollikainen M, Pukkala T (2007) Biodiversity conservation in commercial boreal forestry: the optimal rotation age and retention tree volume. For Sci 53:443-452

Kraft U (2015) Wood end use. For. Rep. 2015 Cond. Use Swiss For. Swiss Federal Office for the Environment FOEN, Bern, and Swiss Federal Institute for Forest, Snow and Landscape Reseach WSL, Birmensdorf, pp 114-115

Kramer K, Degen B, Buschbom J et al (2010) Modelling exploration of the future of European beech (Fagus sylvatica L.) under climate change-range, abundance, genetic diversity and adaptive response. For Ecol Manag 259:2213-2222. doi:10.1016/j. foreco.2009.12.023

Kroiher F, Oehmichen K (2010) Das Potenzial der Totholzakkumulation im deutschen Wald. Schweiz Z Forstwes 161:171-180. doi:10.3188/szf.2010.0171

Läderach T, Streiff H (2016) Jetzt in den jungen Wald investieren. Medienmitteilung zur Publikation der Forststatistik 2015

Lafond V, Lagarrigues G, Cordonnier T, Courbaud B (2014) Unevenaged management options to promote forest resilience for climate change adaptation: effects of group selection and harvesting intensity. Ann For Sci 71:173-186. doi:10.1007/ s13595-013-0291-y

Lauri P, Kallio AMI, Schneider UA (2012) Price of $\mathrm{CO}_{2}$ emissions and use of wood in Europe. For Policy Econ 15:123-131. doi:10. 1016/j.forpol.2011.10.003

Lévesque M, Saurer M, Siegwolf R et al (2013) Drought response of five conifer species under contrasting water availability suggests high vulnerability of Norway spruce and European larch. Glob Change Biol 19:3184-3199. doi:10.1111/gcb.12268

Lexer M, Brooks R (2005) Decision support for multiple purpose forestry. For Ecol Manag 207:1-3. doi:10.1016/j.foreco.2004.11.002

Mette T, Dolos K, Meinardus C et al (2013) Climatic turning point for beech and oak under climate change in central Europe. Ecosphere. doi:10.1890/ES13-00115.1 
Mina M, Bugmann H, Klopcic M, Cailleret M (2015) Accurate modeling of harvesting is key for projecting future forest dynamics: a case study in the Slovenian mountains. Reg Environ Change. doi:10.1007/s10113-015-0902-2

Mina M, Bugmann H, Cordonnier T et al (2016) Future ecosystem services from European mountain forests under climate change. J Appl Ecol. doi:10.1111/1365-2664.12772

Morier A (2012) Umsetzung des naturnahen Waldbaus im Kanton Aargau. Haltung des kantonalen Forstdienstes

Morin X, Fahse L, de Mazancourt C et al (2014) Temporal stability in forest productivity increases with tree diversity due to asynchrony in species dynamics. Ecol Lett. doi:10.1111/ele.12357

Müller J, Bütler R (2010) A review of habitat thresholds for dead wood: a baseline for management recommendations in European forests. Eur J For Res 129:981-992. doi:10.1007/s10342-010-0400-5

Nabuurs G-J, Delacote P, Ellison D et al (2015) A new role for forests and the forest sector in the EU post-2020 climate targets. From Science to Policy 2. European Forest Institute

Netherer S, Matthews B, Katzensteiner K et al (2015) Do waterlimiting conditions predispose Norway spruce to bark beetle attack? New Phytol 205:1128-1141. doi:10.1111/nph.13166

Neuner S, Albrecht A, Cullmann D et al (2015) Survival of Norway spruce remains higher in mixed stands under a dryer and warmer climate. Glob Change Biol 21:935-946. doi:10.1111/gcb.12751

Niedermann-Meier S, Mordini M, Bütler R, Rotach P (2010) Habitatbäume im Wirtschaftswald: ökologisches Potenzial und finanzielle Folgen für den Betrieb. Schweiz Z Forstwes 161:391-400. doi:10.3188/szf.2010.0391

Pedro MS, Rammer W, Seidl R (2014) Tree species diversity mitigates disturbance impacts on the forest carbon cycle. Oecologia 177:619-630. doi:10.1007/s00442-014-3150-0

Perhans K, Glöde D, Gilbertsson J et al (2011) Fine-scale conservation planning outside of reserves: cost-effective selection of retention patches at final harvest. Ecol Econ 70:771-777. doi:10. 1016/j.ecolecon.2010.11.014

Peters DM, Wirth K, Böhr B et al (2015) Energy wood from forestsstakeholder perceptions in five European countries. Energy Sustain Soc. doi:10.1186/s13705-015-0045-9

Pluess AR, Frank A, Heiri C et al (2016) Genome-environment association study suggests local adaptation to climate at the regional scale in Fagus sylvatica. New Phytol 210:589-601. doi:10.1111/nph.13809

Pretzsch H, Grote R, Reineking B et al (2008) Models for forest ecosystem management: a European perspective. Ann Bot 101:1065-1087. doi:10.1093/aob/mcm246

Pukkala T, Laiho O, Lähde E (2016) Continuous cover management reduces wind damage. For Ecol Manag 372:120-127. doi:10. 1016/j.foreco.2016.04.014

Rosenvald R, Lõhmus A (2008) For what, when, and where is greentree retention better than clear-cutting? A review of the biodiversity aspects. For Ecol Manag 255:1-15. doi:10.1016/j. foreco.2007.09.016

Rosenvald R, Lõhmus A, Kraut A, Remm L (2011) Bird communities in hemiboreal old-growth forests: the roles of food supply, stand structure, and site type. For Ecol Manag 262:1541-1550. doi:10. 1016/j.foreco.2011.07.002

Schmidt UE (2009) Wie erfolgreich war das Dauerwaldkonzept bislang: eine historische Analyse. Schweiz Z Forstwes 160:144-151. doi:10.3188/szf.2009.0144

Seidl R, Rammer W, Jäger D et al (2007) Assessing trade-offs between carbon sequestration and timber production within a framework of multi-purpose forestry in Austria. For Ecol Manag 248:64-79. doi:10.1016/j.foreco.2007.02.035

Seidl R, Schelhaas M-J, Lexer MJ (2011) Unraveling the drivers of intensifying forest disturbance regimes in Europe. Glob Change Biol 17:2842-2852. doi:10.1111/j.1365-2486.2011.02452.x
Stadelmann G, Herold A, Didion M et al (2016) Holzerntepotenzial im Schweizer Wald: simulation von Bewirtschaftungsszenarien. Schweiz Z Forstwes 167:152-161. doi:10.3188/szf.2016.0152

Stierlin HR, Zinggeler J (2001) Terrestrial inventory. In: Brassel P, Lischke H (eds) Swiss National Forest Inventory: methods and models of the second assessment. Swiss Federal Research Institute WSL, Birmensdorf, pp 65-87

Stocker R, Burger T, Elsener O et al (2002) Die Waldstandorte des Kantons Aargau. Finanzdepartment des Kantons Aargau, Abteilung Wald, Aarau

Streiff H (2014) Mehr Fitness statt Forschung im Wald und im Sägewerk. Holz-Zentralblatt 40:963

Sweeney OFM, Wilson MW, Irwin S et al (2010) Are bird density, species richness and community structure similar between native woodlands and non-native plantations in an area with a generalist bird fauna? Biodivers Conserv 19:2329-2342. doi:10.1007/s10531-010-9844-7

Tarp P, Buongiorno J, Helles F et al (2005) Economics of converting an even-aged Fagus sylvatica stand to an uneven-aged stand using target diameter harvesting. Scand J For Res 20:63-74. doi:10.1080/02827580510008176

Temperli C, Bugmann H, Elkin C (2012) Adaptive management for competing forest goods and services under climate change. Ecol Appl 22:2065-2077. doi:10.1890/12-0210.1

Temperli C, Bugmann H, Elkin C (2013) Cross-scale interactions among bark beetles, climate change, and wind disturbances: a landscape modeling approach. Ecol Monogr 83:383-402. doi:10. 1890/12-1503.1

Temperli C, Stadelmann G, Thürig E, Brang P (2017) Silvicultural strategies for increased timber harvesting in a central European mountain landscape. Eur J For Res 136:493-509. doi:10.1007/ s10342-017-1048-1

Thom D, Rammer W, Seidl R (2017) Disturbances catalyze the adaptation of forest ecosystems to changing climate conditions. Glob Change Biol 23:269-282. doi:10.1111/gcb.13506

Thürig E, Kaufmann E (2010) Increasing carbon sinks through forest management: a model-based comparison for Switzerland with its Eastern Plateau and Eastern Alps. Eur J For Res 129:563-572. doi:10.1007/s10342-010-0354-7

Thürig E, Kaufmann E, Frisullo R, Bugmann H (2005) Evaluation of the growth function of an empirical forest scenario model. For Ecol Manag 204:53-68. doi:10.1016/j.foreco.2004.07.070

Tikkanen O-P, Matero J, Mönkkönen M et al (2012) To thin or not to thin: bio-economic analysis of two alternative practices to increase amount of coarse woody debris in managed forests. Eur J For Res 131:1411-1422. doi:10.1007/s10342-012-0607-8

Traub B, Meile R, Speich S, Rösler E (2017) The data storage and analysis system of the Swiss National Forest Inventory. Comput Electron Agric 132:97-107. doi:10.1016/j.compag.2016.11.016

UNECE-FAO (2011) The European Forest sector outlook study II: 2010-2030. United Nations, Geneva

Verkerk PJ, Mavsar R, Giergiczny M et al (2014) Assessing impacts of intensified biomass production and biodiversity protection on ecosystem services provided by European forests. Ecosyst Serv 9:155-165. doi:10.1016/j.ecoser.2014.06.004

Verscheure P (1998) Energiegehalt von Hackschnitzeln-Überblick und Anleitung zur Bestimmung. Forstliche Versuchs- und Forschungsanstalt Baden-Württemberg, Freiburg im Breisgau

Vuidot A, Paillet Y, Archaux F, Gosselin F (2011) Influence of tree characteristics and forest management on tree microhabitats. Biol Conserv 144:441-450. doi:10.1016/j.biocon.2010.09.030

WaldSchweiz (2017) Preise Stammholz-Roholz-Preiserhebung 2016/16. WaldSchweiz-Verband Waldeigentümer. http:// www.waldschweiz.ch/schweizer-wald/holzmarkt/preise-stamm holz/preise-stammholz.html. Accessed 10 May 2017 
WaldSchweiz, Forstunternehmer Schweiz, Holzindustrie Schweiz et al (2016) Energieholzpreise 2016/2017. Wald Holz 11:19

Werner F, Taverna R, Hofer P et al (2010) National and global greenhouse gas dynamics of different forest management and wood use scenarios: a model-based assessment. Environ Sci Policy 13:72-85. doi:10.1016/j.envsci.2009.10.004

Wittwer R (2016) 20 Jahre Naturschutzprogramm Wald. Umw Aargau, pp 45-48
Yousefpour R, Hanewinkel M (2014) Balancing decisions for adaptive and multipurpose conversion of Norway spruce (Picea abies L. Karst) monocultures in the Black Forest area of Germany. For Sci 60:73-84. doi:10.5849/forsci.11-125

Zubler EM, Scherrer SC, Croci-Maspoli M et al (2014) Key climate indices in Switzerland; expected changes in a future climate. Clim Change 123:255-271. doi:10.1007/s10584-013-1041-8 